\title{
WIPP Facility Work Plan for Solid Waste Management Units and Areas of Concern
}

\author{
February 2002
}

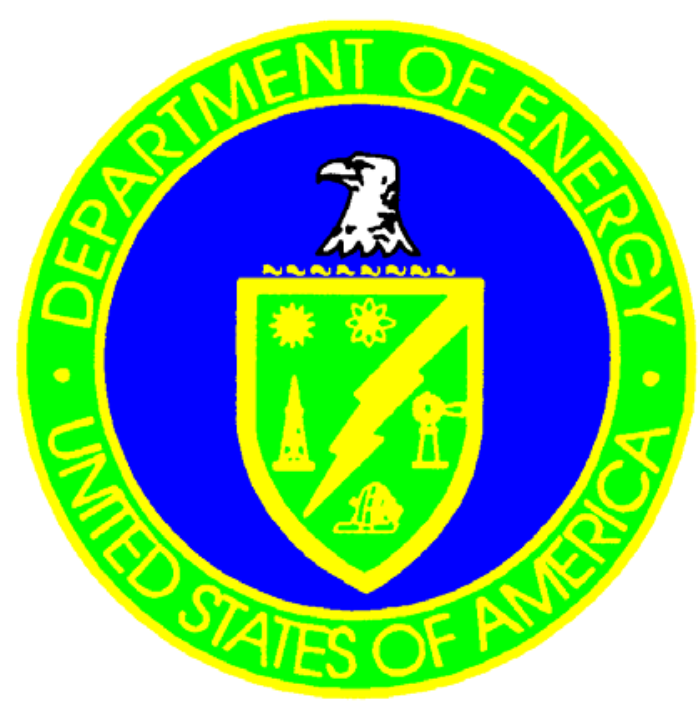

Processing and final preparation of this report was performed by the Waste Isolation Pilot Plant Management and Operating Contractor for the U.S. Department of Energy under Contract No. DE-AC04-01AL66444 


\section{TABLE OF CONTENTS}

ABBREVIATIONS AND ACRONYMS .................. iii

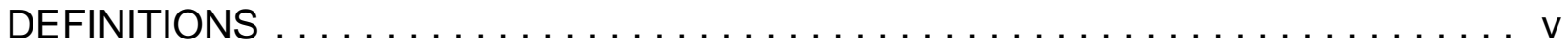

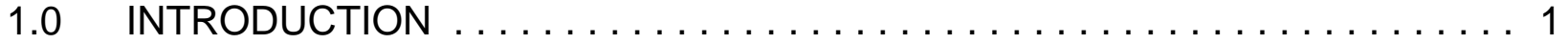

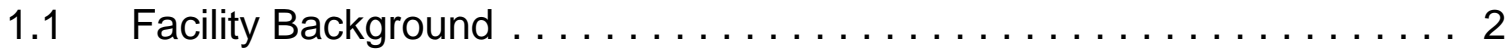

1.2 SWMUs and AOCs Identified in the Permit $\ldots \ldots \ldots \ldots \ldots \ldots \ldots 2$

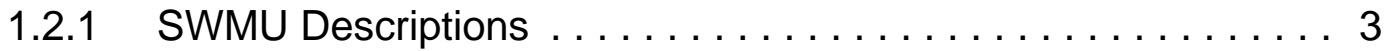

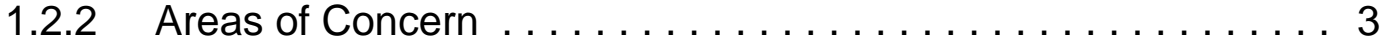

$1.3 \quad$ Work Plan Organization $\ldots \ldots \ldots \ldots \ldots \ldots \ldots \ldots \ldots \ldots$

2.0 PROJECT MANAGEMENT PLAN . . . . . . . . . . . . . . 4

2.1 Technical Approach, Schedules, Budget, and Key Project Personnel . . 4

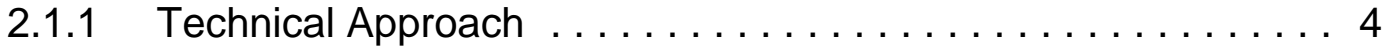

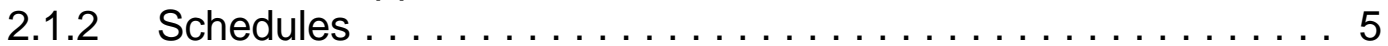

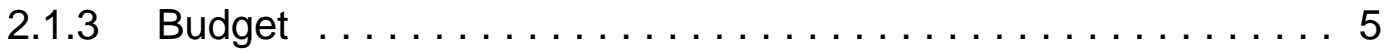

2.1.4 Key Project Personnel $\ldots \ldots \ldots \ldots \ldots \ldots \ldots \ldots \ldots$

2.2 Key Project Personnel Qualifications $\ldots \ldots \ldots \ldots \ldots \ldots \ldots \ldots 5$

2.3 Overall Management Approach to the RFI $\ldots \ldots \ldots \ldots \ldots \ldots \ldots$

3.0 DATA COLLECTION QUALITY ASSURANCE PLAN $\ldots \ldots \ldots \ldots \ldots \ldots$

3.1 Data Collection Quality Assurance Strategy $\ldots \ldots \ldots \ldots \ldots \ldots \ldots$

3.1.1 Intended Data Uses . . . . . . . . . . . . . . . . 7

3.1.2 Methods and Procedures to Assess Precision, Accuracy,

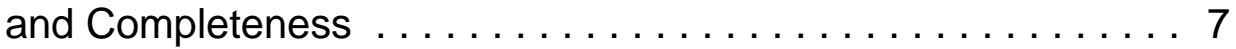

3.1.3 Schedule and Information to be Provided in Quality

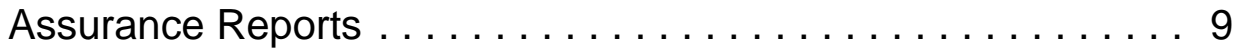

3.2 Sampling and Field Measurements .................. 9

3.2.1 Selecting Sampling and Field Measurements Locations .... 10

3.2 .3 Sampling Conditions . . . . . . . . . . . . . . . . 11

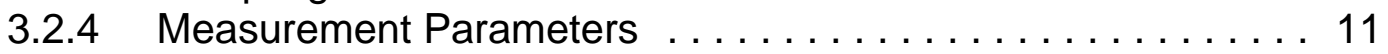

3.2.5 Frequency of Sampling, and Length of Sampling Period ..... 11

3.2.6 Types and Number of Samples . . . . . . . . . . . . 11

3.2.7 Procedures to Prevent Contamination .............. 11

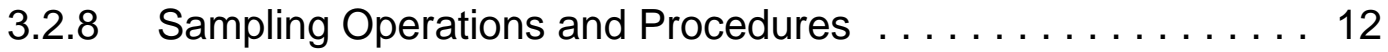

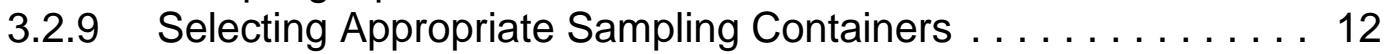

3.2 .10 Preserving Samples . . . . . . . . . . . . . . . 12

3.2.11 Controlling Chain of Custody . ............... 13

3.2.12 Disposing of Contaminated Materials Generated by Activities . 13

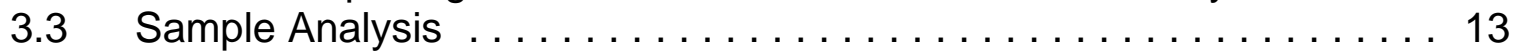

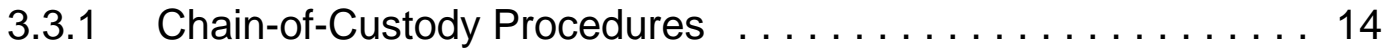

3.3.2 Sample Storage Procedures and Holding Times . . . . . . . 14

3.3.3 Sample Preparation Methods .................. 14

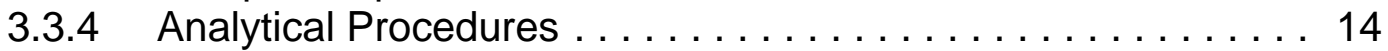

3.3.5 Calibration Procedures and Frequency $\ldots \ldots \ldots \ldots \ldots 14$ 
3.3.6 Data Reduction, Validation, and Reporting . . . . . . . . 15

3.3.7 Frequency of Internal Quality Control Checks and Laboratory Performance Audits $\ldots \ldots \ldots \ldots \ldots \ldots \ldots$

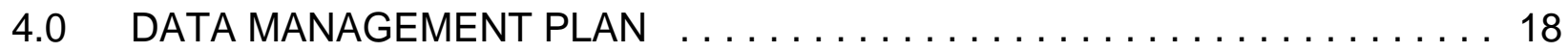

4.1 Data Documentation Materials and Procedures $\ldots \ldots \ldots \ldots \ldots \ldots 18$

4.1 .1 Field Data . . . . . . . . . . . . . . . . . . . . 19

4.1 .2 Analytical Data ...................... 19

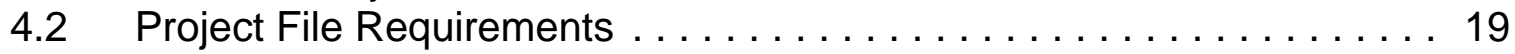

4.3 Project-Related Progress Reporting Procedures and Documents . . . 19

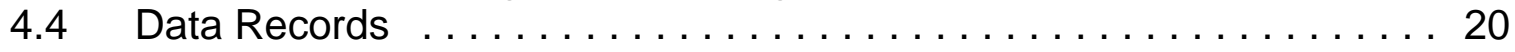

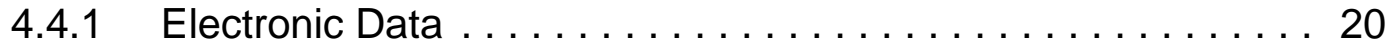

4.4 .2 Hard-Copy Data . . . . . . . . . . . . . . . . . 21

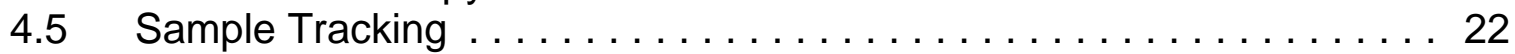

5.0 SITE SAFETY AND HEALTH PLAN $\ldots \ldots \ldots \ldots \ldots \ldots \ldots \ldots \ldots \ldots \ldots$

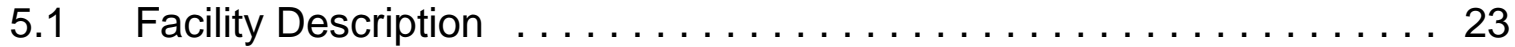

5.2 Description of Known Hazards and Evaluation of Risks . . . . . . . 25

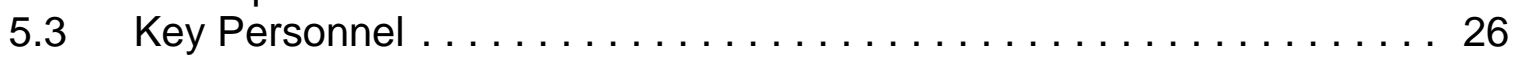

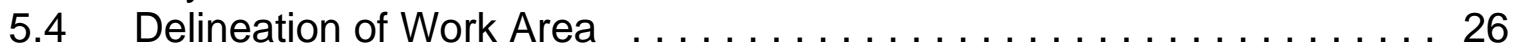

5.5 Levels of Personnel Protection $\ldots \ldots \ldots \ldots \ldots \ldots \ldots \ldots \ldots \ldots 26$

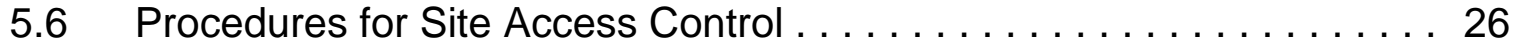

5.7 Decontamination Procedures for Personnel and Equipment . . . . . 26

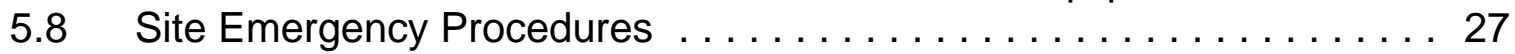

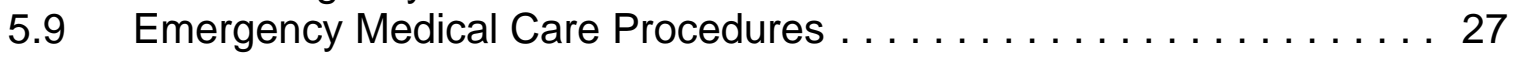

5.10 Environmental Field Monitoring Program $\ldots \ldots \ldots \ldots \ldots \ldots \ldots 27$

5.11 Routine and Special Training Requirements for Responders . . . . . . 27

5.12 Procedures for Protecting Workers from Weather-Related Problems . 27

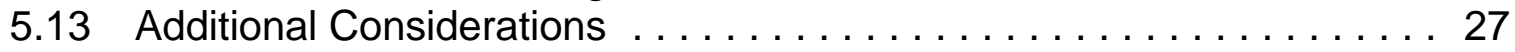

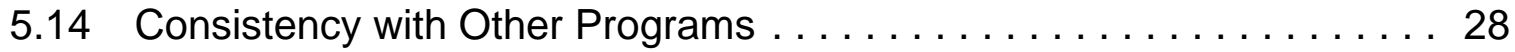

6.0 COMMUNITY RELATIONS PLAN $\ldots \ldots \ldots \ldots \ldots \ldots \ldots \ldots \ldots \ldots \ldots$

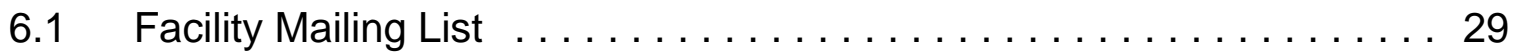

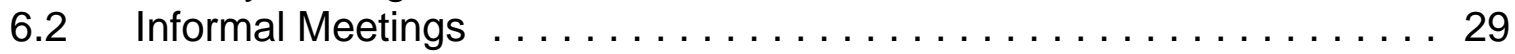

6.3 News Releases, Fact Sheets, Approved RFI Work Plans, RFI

Reports, Special Permit Conditions Reports, and Quarterly

Progress Reports ............................ 29

6.4 Information Repositories . . . . . . . . . . . . . . . 29

6.5 Updates of Materials in the Information Repositories and Reading Rooms ............................. 30

6.6 Quarterly Technical Progress Reports $\ldots \ldots \ldots \ldots \ldots \ldots \ldots \ldots 30$

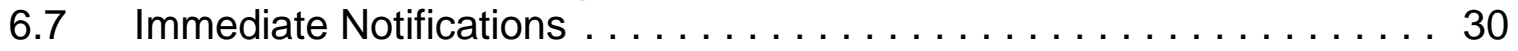

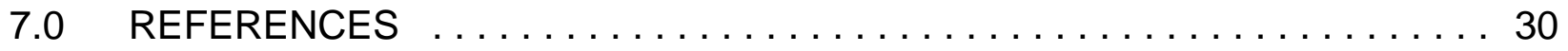




\section{ABBREVIATIONS AND ACRONYMS}

\begin{tabular}{|c|c|}
\hline $\begin{array}{l}\text { ACAA } \\
\text { AOC } \\
\text { ASTM }\end{array}$ & $\begin{array}{l}\text { Accelerated Corrective Action Approach } \\
\text { Area of Concern } \\
\text { American Society for Testing and Materials }\end{array}$ \\
\hline $\begin{array}{l}\text { CBFO } \\
\text { CFR } \\
\text { CLP } \\
\text { CMR } \\
\text { COC }\end{array}$ & $\begin{array}{l}\text { Carlsbad Field Office } \\
\text { Code of Federal Regulations } \\
\text { Contract Laboratory Program } \\
\text { Central Monitoring Room } \\
\text { Chain of Custody }\end{array}$ \\
\hline $\begin{array}{l}\text { DCQAP } \\
\text { DOE } \\
\text { DQO } \\
\text { DSP }\end{array}$ & $\begin{array}{l}\text { Data Collection Quality Assurance Plan } \\
\text { U.S. Department of Energy } \\
\text { Data Quality Objective } \\
\text { Duval Sulphur \& Potash Company }\end{array}$ \\
\hline $\begin{array}{l}\text { EC } \\
\text { EPA } \\
\text { ES\&H En }\end{array}$ & $\begin{array}{l}\text { Environmental Compliance } \\
\text { U.S. Environmental Protection Agency } \\
\text { nnment, Safety and Health }\end{array}$ \\
\hline FWP & Facility Work Plan \\
\hline GIS & Geographic Information System \\
\hline HSWA & Hazardous and Solid Waste Amendments \\
\hline $\begin{array}{l}\text { IH } \\
\text { IMC }\end{array}$ & $\begin{array}{l}\text { Industrial Hygiene } \\
\text { International Minerals \& Chemical Corporation }\end{array}$ \\
\hline JHA & Job Hazard Analysis \\
\hline LIMS & Laboratory Information Management System \\
\hline $\begin{array}{l}\text { MS } \\
\text { MSD }\end{array}$ & $\begin{array}{l}\text { Matrix Spike } \\
\text { Matrix Spike Duplicate }\end{array}$ \\
\hline $\begin{array}{l}\text { NFA } \\
\text { NMAC } \\
\text { NMED }\end{array}$ & $\begin{array}{l}\text { No Further Action } \\
\text { New Mexico Administrative Code } \\
\text { New Mexico Environment Department }\end{array}$ \\
\hline OSWER & Office of Solid Waste and Emergency Response \\
\hline $\begin{array}{l}\text { PA } \\
\text { PPE }\end{array}$ & $\begin{array}{l}\text { Public Address (system) } \\
\text { Personal Protective Equipment }\end{array}$ \\
\hline
\end{tabular}




\begin{tabular}{ll} 
QA & Quality Assurance \\
QC & Quality Control \\
\multicolumn{1}{l}{ RCRA } & Resource Conservation and Recovery Act \\
RFI & RCRA Facility Investigation \\
RIDS & Record Inventory and Disposition Schedule \\
| & \\
SAP & Sampling and Analysis Plan \\
SNS & Site Notification System \\
SOP & Standard Operating Procedure \\
SWMU & Solid Waste Management Unit \\
| TCLP & Toxicity Characteristic Leaching Procedure \\
I UPS & Uninterruptible Power Supply \\
VRA & Voluntary Release Assessment \\
WLWA & WIPP Land Withdrawal Area \\
WIPP & Waste Isolation Pilot Plant \\
WTS & Westinghouse TRU Solutions, LLC
\end{tabular}




\section{DEFINITIONS}

Area of Concern $(A O C)^{1}$ - Any discernable unit or area which, in the opinion of the New Mexico Environment Department (NMED) Secretary, may have received solid or hazardous waste or waste containing hazardous constituents at any time.

Hazardous Constituent ${ }^{1}$ - Any constituent identified in 20 NMAC [New Mexico Administration Code] 4.1.200 (incorporating Title 40 Code of Federal Regulations [CFR] \& 261 Appendix VIII), any constituent identified in 20 NMAC 4.1.500 (incorporating 40 CFR § 264 Appendix IX), any constituent identified in a hazardous waste listed in 20 NMAC 4.1.200 (incorporating 40 CFR § 261 Subpart D), or any constituent identified in a toxicity characteristic waste in 20 NMAC 4.1.200 (incorporating 40 CFR § 264.24, Table 1).

Hazardous Waste ${ }^{1}$ - A solid waste (or combination of solid wastes) which, because of its quantity, concentration, or physical, chemical, or infectious characteristics, may cause, or notably contribute to, an increase in mortality or an increase in serious irreversible, or incapacitating reversible, illness; or pose a substantial present or potential hazard to human health or the environment when improperly treated, stored, transported, or disposed of, or otherwise managed.

HSWA $^{1}$ - The 1984 Hazardous and Solid Waste Amendments to the Resource Conservation and Recovery Act (RCRA).

Land Withdrawal Act - Waste Isolation Pilot Plant (WIPP) Land Withdrawal Act (Public Law 102-579, as amended by Public Law 104-201) transferred the responsibility for the management of the WIPP Land Withdrawal Area (WLWA) from the United States Secretary of the Interior to the United States Secretary of Energy. These lands "are withdrawn from all forms of entry, appropriation, and disposal under the public land laws" and are reserved for the use of the Secretary of Energy "for the construction, experimentation, operation, repair and maintenance, disposal, shutdown, monitoring, decommissioning, and other activities, associated with the purposes of WIPP."

RCRA $^{1}$ - The Resource Conservation and Recovery Act of 1980, as amended by the HSWA in 1984.

Release $^{1}$ - Any spilling, leaking, pouring, emitting, emptying, discharging, injecting, pumping, escaping, leaching, dumping, or disposing of hazardous wastes (including hazardous constituents) into the environment (including the abandonment or discarding of barrels, containers, and other closed receptacles containing hazardous wastes or hazardous constituents).

1 These definitions were extracted directly from the October 27, 1999, Waste Isolation Pilot Plant Hazardous Waste Facility Permit. For purposes of this document, acronyms are defined. 
Solid Waste Management ${ }^{1}$ - The systematic administration of activities that provide for the collection, source separation, storage, transportation, transfer, processing, treatment, and disposal of solid waste.

Solid Waste Management Unit (SWMU) ${ }^{1}$ - Any discernible unit at which solid wastes have been placed at any time, irrespective of whether the unit was intended for the management of solid or hazardous waste. Such units include any area at a facility at which solid wastes have been routinely and systematically released. The definition includes regulated units (i.e., landfills, surface impoundments, waste piles, and land treatment units), but does not include passive leakage or one-time spills from production areas and units in which wastes have not been managed (e.g., product storage areas).

Stratified Random Sampling - A sampling process in which the area of nonrandom chemical heterogeneity (e.g., a drilling mud pit) is stratified (e.g., vertical extent of drilling mud, soil cover, and native soil below drilling mud). After stratification of the area, a simple random sample is collected from the solid waste stratum.

WIPP Land Withdrawal Area (WLWA) - The 16-section federal land area under the jurisdiction of the U.S. Department of Energy (DOE) containing and surrounding the WIPP facility. This area is located in Eddy County, New Mexico, 26 miles east of Carlsbad, New Mexico. 


\section{$1.0 \quad$ INTRODUCTION}

This 2002 Facility Work Plan (FWP) has been prepared as required by Module VII, Permit Condition VII.U.3 of the Waste Isolation Pilot Plant (WIPP) Hazardous Waste Facility Permit, NM4890139088-TSDF (the Permit) (New Mexico Environment Department [NMED], 1999a), and incorporates comments from the NMED received on December 6, 2000 (NMED, 2000a). This February 2002 FWP describes the programmatic facility-wide approach to future investigations at Solid Waste Management Units (SWMU) and Areas of Concern (AOC) specified in the Permit. The Permittees ${ }^{1}$ are evaluating data from previous investigations of the SWMUs and AOCs against the most recent guidance proposed by the NMED. Based on these data, and completion of the August 2001 sampling requested by the NMED, the Permittees expect that no further sampling will be required and that a request for No Further Action (NFA) at the SWMUs and AOCs will be submitted to the NMED.

This FWP addresses the current Permit requirements. It uses the results of previous investigations performed at WIPP and expands the investigations as required by the Permit. As an alternative to the Resource Conservation and Recovery Act (RCRA) Facility Investigation (RFI) specified in Module VII of the Permit, current NMED guidance identifies an Accelerated Corrective Action Approach (ACAA) that may be used for any SWMU or AOC (NMED, 1998). This accelerated approach is used to replace the standard RFI Work Plan and Report sequence with a more flexible decisionmaking approach. The ACAA process allows a facility to exit the schedule of compliance contained in the facility's Hazardous and Solid Waste Amendments (HSWA) permit module and proceed on an accelerated time frame. Thus, the ACAA process can be entered either before or after an RFI Work Plan. According to the NMED's guidance, a facility can prepare an RFI Work Plan or Sampling and Analysis Plan (SAP) for any SWMU or AOC (NMED, 1998). Based on this guidance, a SAP constitutes an acceptable alternative to the RFI Work Plan specified in the Permit. The NMED accepted that the Permittees are using the ACAA in a letter dated April 20, 2000.

The SWMU program at WIPP began in 1994 under U.S. Environmental Protection Agency (EPA) regulatory authority. The NMED received regulatory authority from the EPA on January 2, 1996. A Phase I RFI was completed at WIPP as part of a Voluntary Release Assessment (VRA). The risk-based decision criteria recommended by the EPA for the VRA were contained in a proposed Corrective Action rule for SWMUs (EPA, 1990). EPA Region VI has issued new risk-based screening criteria applicable to the WIPP SWMUs and AOCs (EPA, 2000). The NMED has also issued risk-based screening criteria (NMED, 2000b). The NMED has indicated that chemical concentrations in all soil samples must be compared against stringent residential risk-based screening criteria instead of industrial risk-based screening criteria. The Permittees believe that the industrial risk-based screening criteria are conservative for evaluating potential human exposure to SWMU constituents. In the NFA request to the NMED, the

1 The Permittees are the U.S. Department of Energy Carlsbad Field Office and Westinghouse TRU Solutions LLC. 
Permittees will compare existing sampling results to the residential and industrial riskbased screening criteria to demonstrate that the facility meets both sets of criteria.

\subsection{Facility Background}

The WIPP facility consists of surface buildings and structures, an underground network of excavated openings, and vertical shafts that connect the surface and subsurface areas. Waste, equipment, and personnel enter the underground facility through designated shafts.

The underground hazardous waste disposal units, defined as waste panels, are located 2,150 feet (655 meters) below ground surface. The waste panels consist of seven rooms and two access drifts each. Each room is approximately 300 feet (91 meters) long, 33 feet (10 meters) wide, and 13 feet (4 meters) high. Access drifts connect the rooms and have the same cross section. The hazardous waste management units are not addressed within this FWP.

\section{SWMUs and AOCs Identified in the Permit}

The Permit identifies 15 SWMUs requiring an RFI, 3 SWMUs not requiring an RFI (the hazardous waste management units), and 8 AOCs in the 16-section WIPP Land Withdrawal Area (WLWA). The WIPP Land Withdrawal Act (Public Law 102-579), as amended by Public Law 104-201) created the WLWA in October 1992. This Act transferred the responsibility for the management of the WLWA from the Secretary of the Interior to the Secretary of Energy. In accordance with sections 3(a)(1) and (3) of the Act, these lands ". . . are withdrawn from all forms of entry, appropriation, and disposal under the public land laws . . . " and are reserved for the use of the Secretary of Energy ". . . for the construction, experimentation, operation, repair and maintenance, disposal, shutdown, monitoring, decommissioning, and other activities, associated with the purposes of WIPP as set forth in Section 213 of the Department of Energy National Security and Military Applications of Nuclear Energy Act of 1980 (Public Law 96-164; 93 Statute 1259, 1265) and this Act." Some of the SWMUs and AOCs were identified in the original RCRA Part B Permit Application for the facility (DOE/WIPP 91-005, Revision 0), and were included in a RCRA Facility Assessment performed by the NMED (NMED/DOE/AIP 94/1, 1994). The 15 SWMUs and 8 AOCs identified in the Permit are associated with (1) natural resource exploration activities prior to the development of WIPP, or (2) early WIPP mineral assessment and geological studies to support the development of the facility, or (3) facility construction. More information on each SWMU and AOC can be found in Assessment of Solid Waste Management Units at the Waste Isolation Pilot Plant (NMED, 1994), the WIPP RCRA Facility Assessment, Final Voluntary Release Assessment/Corrective Action Report (DOE, 1996), Supplemental Information Requested by the New Mexico Environment Department for Solid Waste Management Units (DOE, 1997a), and Technical Support Document, Exclusion/Inclusion of Solid Waste Management Units and Areas of Concern (NMED, 1999). 


\subsubsection{SWMU Descriptions}

The 15 SWMUs included in the Permit that require an RFI are:

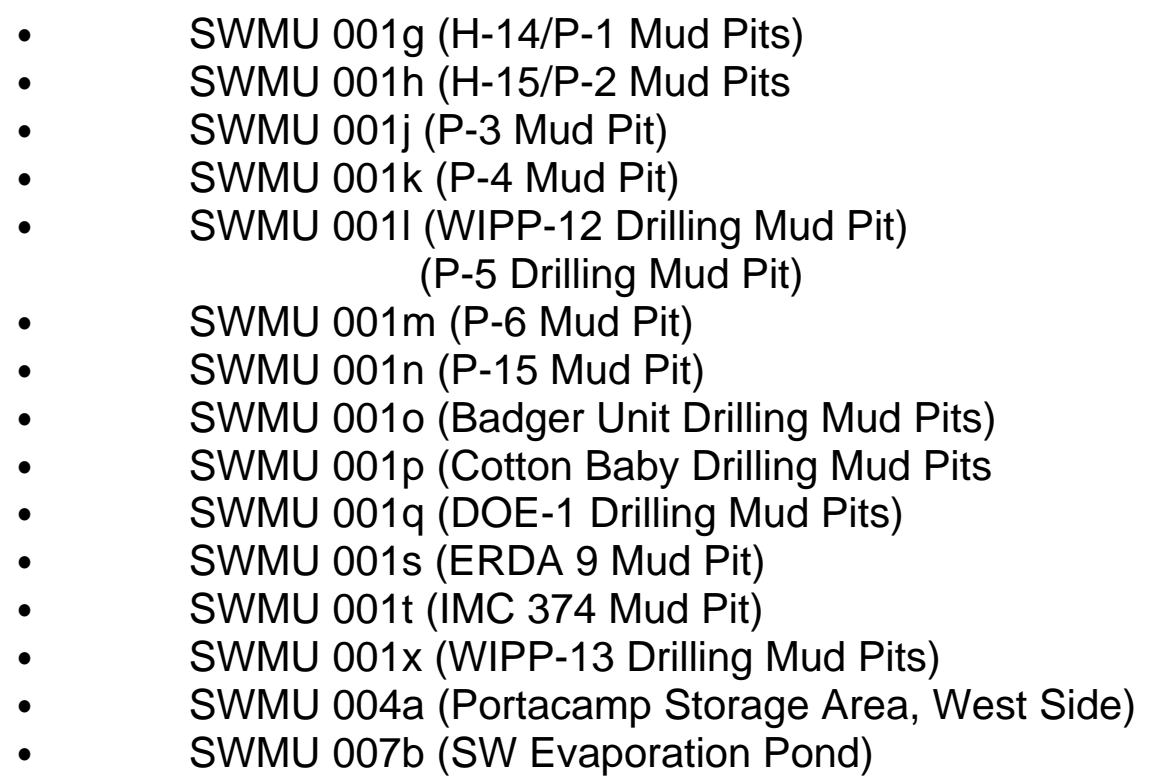

\subsubsection{Areas of Concern}

The eight AOCs included in the Permit are:

$\begin{array}{ll}- & \text { AOC 001r (D-123 Mud Pit) } \\ \text { - } & \text { AOC 001u (IMC-376 Mud Pit) } \\ \text { - } & \text { AOC 001v (IMC-456 Mud Pit) } \\ \text { - } & \text { AOC 001w (IMC-457 Mud Pit) } \\ \text { - } & \text { AOC 001ac (DSP-207 Mud Pit) } \\ & \text { AOC 010b (Waste Handling Shaft Sump) } \\ & \text { AOC 010c (Exhaust Shaft Sump) }\end{array}$

\subsection{Work Plan Organization}

As required by the Permit, this FWP considers the following primary topics: Section 2.0 presents the project management plan; Section 3.0 presents the Data Collection Quality Assurance Plan (DCQAP); Section 4.0 presents the Data Management Plan; Section 5.0 presents the Site Safety and Health Plan; and Section 6.0 presents the Community Relations Plan. Finally, references for this FWP are presented in Section 7.0. The organization of this FWP follows the requirements of Module VII of the Permit. 


\subsection{PROJECT MANAGEMENT PLAN}

This section of the FWP provides a generalized overview of the Project Management Plan for conducting future SWMU sampling activities. As such, this project management plan responds to the requirements in Sections VII.M and VII.U.3.j of the Permit. The technical approach, schedules, budget, key personnel, key personnel qualifications, and the overall management approach for the SAP are described in the following subsections.

\subsection{Technical Approach, Schedules, Budget, and Key Project Personnel}

\subsubsection{Technical Approach}

The overall program objectives for the investigation of the SWMUs and AOCs at WIPP include:

- Implement a plan to characterize the nature and extent of hazardous constituents sufficiently to make corrective action decisions (including NFA) for SWMUs and AOCs.

- Implement SWMU sampling activities using existing site information, regulatory requirements, and required decisions utilizing the EPA RFI planning documents and Data Quality Objective (DQO) process.

- $\quad$ Perform needed investigations in a cost-effective manner.

- $\quad$ Comply with the Permit requirements for the SWMUs/AOCs.

EPA guidance states, "the scope and complexity of remedial investigations will depend on the nature and extent of the contamination, whether the releases have migrated beyond the facility boundary, the amount of existing information on the site, the likely risk at the site, and other pertinent factors" (EPA, 1990, and 2000). Because a large body of analytical, technical, and risk information exists for these SWMUs/AOCs, these data have been considered for planning and negotiating specific goals and activities.

Because of the quantity of information obtained during the VRA program at WIPP, the first phase of the RFI has already been performed. The technical approach for implementation of SWMU sampling activities involves further investigation of SWMUs where releases of hazardous constituents were identified during the VRA. Upon mutual consent of the NMED and the Permittees, a second round of sampling was completed in August 2001. The agreed-upon sampling occurred at four SWMUs. These four SWMUs were SWMU 001L, 001P, 001Q, and 004A. This sampling completed the assessment of the rate and extent of possible contaimate migration at the SWMUs. The sampling data was communicated to the NMED via the first Quarterly Report submitted in November 2001. 
Program implementation will incorporate the EPA's DQO process to tailor data gathering strategies for the purpose of making corrective action decisions (EPA, 1987, 1993, 1994b, 1998a). The DQO process will be used to ensure that environmental data are adequate, scientifically valid, defensible, and of an appropriate level of quality, given the intended use for the data in corrective action decision making. The DQO specifications are defined in the SAP.

If additional risk evaluations are required for the SWMUs/AOCs, appropriate EPA and NMED guidance documents will be used during the evaluations (EPA, 1989b, 1992, 1996, 1997a, 1998b).

\subsubsection{Schedules}

The first FWP was submitted to the NMED on February 24, 2000 (90 days after the effective date of the Permit). This revised FWP is the second annual update of the February 2000 document. Annual reviews to the FWP will be performed as required, and updates will be completed as necessary.

\subsubsection{Budget}

Budget allocations for implementation of SWMU sampling activities will be made based on a defined scope of work and on specific, well-defined program decisions.

\subsubsection{Key Project Personnel}

A number of WIPP personnel will be involved in the implementation of SWMU sampling activities. The SWMU Project Manager from Environmental Compliance (EC) will be responsible for coordinating SWMU sampling activities. The SWMU Project Manager will marshal and monitor needed resources for the program and serve as liaison between other cognizant organizations. The SWMU Project Manager will report to the DOE through the Environment, Safety, and Health (ES\&H) Manager.

Other organizations that may be involved in SWMU sampling activities include the Sampling Team, ETSG (Enterprise Technologies Solutions Group) (for electronic data management and processing support), Industrial Safety and Hygiene (for health and safety issues), Strategic Planning and Communication (for community relations support), Quality Assurance, Environmental Compliance, and subcontractors. The actual involvement of these organizations and their direct responsibilities will be solicited as needed by the SWMU Project Manager.

\subsection{Key Project Personnel Qualifications}

As described in Section 2.1.4, a number of WIPP personnel will be involved in future SWMU sampling activities. Prior to implementation of SWMU sampling activities, the SWMU Project Manager will select qualified individuals who will be responsible for implementing SWMU sampling activities. 
Qualifications for these responsible individuals will include necessary training and experience for the sampling tasks in their area of responsibility.

\subsection{Overall Management Approach to the RFI}

SWMU sampling activities will be managed by qualified WIPP personnel using cost and schedule control measures, and adhering to strict quality assurance and quality control (QA/QC) criteria. Cost control will benefit WIPP and the taxpayers by ensuring that funds are expended in the most cost-effective manner. Schedule control will be achieved by monitoring planned versus actual task duration, which will enable the Permittees to monitor progress and ensure that deliverables specified in the Permit are submitted to the NMED in a timely manner. Appropriate QA/QC procedures employed during the process will ensure that DQOs are met.

\subsection{DATA COLLECTION QUALITY ASSURANCE PLAN}

As indicated in Section 1.0, the Permittees are evaluating data from previous investigations of the SWMUs and AOCs against the newly released NMED guidance. Based on these data, the Permittees expect that no further sampling will be required and that a request for a NFA determination at the SWMUs and AOCs will be submitted to the NMED. If further sampling is required, the protocols discussed in this section will be followed. This section of the FWP provides a generalized DCQAP for data collection activities performed as part of sampling activities at WIPP SWMUs. As such, this DCQAP responds to the requirements specified in Sections VII.M and VII.U.3.f of the Permit. This DCQAP also identifies generalized procedures for sample collection and analysis as part of SWMU sampling activities, as documented in existing WIPP plans and procedures. The ACAA sample collection planning document will supplement this DCQAP by further defining the specific procedures and requirements for each sampling activity specified in Section VII.U.3.f of the Permit. Together with the ACAA sample collection planning document, implementation of this DCQAP will produce a complete, detailed, and ongoing record of the data collection and QA activities.

The objectives of the DCQAP are as follows:

- $\quad$ Provide a consistent framework for generating analytical data throughout the sample collection.

- $\quad$ Define data quality goals for data collection based on specifications for precision, accuracy, and completeness.

- $\quad$ Identify procedures that demonstrate that the sampling, analytical, and data reporting systems are achieving program objectives.

- $\quad$ Set forth record-keeping procedures commensurate with project data uses.

- $\quad$ Provide for the generation and documentation of data of known and acceptable quality. 


\subsection{Data Collection Quality Assurance Strategy}

In general, data collection activities are based on risk. The appropriate New Mexico and EPA screening criteria will be selected for use in future risk evaluations at the SWMUs and AOCs in accordance with applicable New Mexico and EPA guidance. Investigation activities are designed to identify and characterize releases of hazardous constituents within SWMUs/AOCs. Additional decision objectives for data collection activities are the effective and cost-efficient implementation of sample collection procedures.

\subsubsection{Intended Data Uses}

The general data use categories identified for each data collection activity are consistent with EPA guidance regarding DQOs. Data quality objectives are qualitative and quantitative statements that specify the quality of the data required to support sample collection decisions, and are based on the end uses of the data to be collected. As such, different data uses may require different levels of data quality. Sample collection during future SWMU sampling activities (if required), will be analyzed to provide definitive data.

The EPA defines definitive data to be:

Generated using rigorous analytical methods and QA protocols in environmental analytical laboratories. Definitive data provide reliable, well-documented identification, quantification, and confirmation of target analytes. Definitive data will generally be required for decisions regarding risk and/or the implementation of corrective measures. The results generated from definitive analyses must be scientifically defensible data that can prove or disprove a hypothesis with no additional information beyond that provided in the data package.

Definitive data will be generated to assess the nature and extent of hazardous constituents and whether these constituents have been released to the surrounding media at concentrations above decision criteria. The necessary level of precision and accuracy for the decision criteria will be consistent with the sampling and analysis methods selected for the investigations.

\subsubsection{Methods and Procedures to Assess Precision, Accuracy, and Completeness}

Data quality objectives for the definitive data collected in support of SWMU sampling activities are defined in this section. Data quality is defined in terms of precision, accuracy, and completeness. 


\section{Precision and Accuracy}

Precision is the measure of mutual agreement among separate measurements of the same property, usually under prescribed similar conditions. Precision describes the effects random errors have on analytical measurements. Precision typically is measured in a system by the relative percent difference between duplicate measurements.

Accuracy is the measure of the agreement of a value with an accepted reference. Accuracy is used to estimate the effect of systematic errors, or biases, on analytical measurements required to make programmatic decisions. Accuracy is typically measured in a system by calculating the percent recovery or percent difference from an analytical standard. Field and laboratory blank data can also reveal systematic errors and biases.

The precision and accuracy of a data set are generally functions of the analytical method and sample matrix. Appropriate methods from SW-846 (EPA, 1997b) will be utilized for analysis of samples collected from SWMUs or AOCs.

Precision and accuracy objectives for definitive sample analyses to be performed in support of SWMU sampling activities will be documented in laboratory standard operating procedures (SOP) to be provided by the subcontractor laboratory for the analytical methods used for specific projects. The laboratory's analytical method SOPS will be based on the standard EPA methods used for sample analysis. The precision and accuracy achieved by the laboratory will be consistent with the requirements established by the laboratory method start-up protocol, as well as applicable EPA method requirements for inorganic analyses. The overall precision and accuracy of the reported results will be evaluated when decisions are made concerning the achievement of performance standards for the SWMU sampling activities.

\section{Completeness}

One hundred percent of the planned samples will be collected in the field. It is expected that 100 percent of the samples will be analyzed successfully, because sufficient material will be available to perform a repeat analysis for any samples invalidated by the laboratory. No corrective action will be considered as long as the completeness is at or above 85 percent for validated sample results. This completeness goal is considered adequate to meet the DQOs for the SAP, based on prior consideration of QA/QC parameters, the sampling design plans, and the proposed data collection activities. Data completeness will be represented as the amount of valid data obtained versus the amount of data expected or planned for a given SAP activity. Data that are rejected through data validation will be counted against completeness goals. The SWMU Project Manager or designated representative will perform the evaluation of completeness. 


\subsubsection{Schedule and Information to be Provided in Quality Assurance Reports}

Quality assurance/quality control assessments and reviews will be performed by the Permittees during and after SWMU sampling activities. Assessment, review, and response actions will be performed in accordance with the established WIPP QA program as documented in the WTS Quality Assurance Program Description (WP 13-1) and the Quality Assurance Project Plan for WIPP Site Effluent and Hazardous Materials Sampling (WP 02-EC.05). Team members participating in SWMU sampling activities are collectively responsible for assessment activities and have authority to implement corrective action or stop work depending on the situation. Examples of project assessment activities that could be applied during the field investigation in accordance with established facility QA protocols are listed below:

- $\quad$ Periodic assessment of measurement data (accuracy, precision, and completeness)

- $\quad$ Performance audits

- $\quad$ Systems audits of field and laboratory operations

- Identification of quality assurance problems and resolutions (corrective actions)

The QA/QC data will be included in a final report detailing results of the field activities. At a minimum, a summary of both the field activities performed and the results for collected data at the conclusion of the field investigation will be prepared. This summary will include the following information, as appropriate:

- Data validation reports summarizing the validation process used and specific comments pertaining to a sample or group of samples

- $\quad$ Summaries of accuracy, precision, and completeness for the field and laboratory data

- $\quad$ Results of performance and systems audits

- Identification and resolution of QA problems

\subsection{Sampling and Field Measurements}

The design of the sampling program is critical to the production of representative data. The EPA identifies four sampling strategies in Chapter 9 of SW-846 (EPA, 1997b). The use of a sampling strategy is based on the prior knowledge of the site and specific material being investigated. A stratified random sampling approach will be used for future sampling activities at the SWMUs and AOCs. 
Stratified Random Sampling is used when there is specific knowledge of the medium to be sampled and sources of chemical constituents. Samples of the medium are collected based on the knowledge that chemical constituents are likely to be distributed in a nonrandomly heterogeneous fashion. In such cases, samples are stratified to isolate areas of potentially elevated chemical concentrations. Factors including history of the area, physical and chemical behavior of contaminants, and physical system effects on contaminant fate and transport are considered when selecting sample sites.

Sampling program design information follows:

- $\quad$ Selecting appropriate sampling and field measurements locations

- Defining a sufficient number of sampling and field measurement sites

- Defining conditions under which sampling or field measurements will be conducted

- $\quad$ Defining which parameters are to be measured and where

- $\quad$ Selecting the frequency of sampling and length of sampling period

- $\quad$ Selecting the types of sample and number of samples to be collected

- Delineating procedures designed to prevent contamination of sampling or field measurements equipment and cross contamination between sampling points

- $\quad$ Documenting field sampling operations and procedures

- $\quad$ Selecting appropriate sample containers

- $\quad$ Preserving samples

- $\quad$ Controlling chain of custody (COC)

- $\quad$ Proper disposition of waste

General sampling guidelines are summarized and/or referenced below. Sampling will be performed in accordance with written documentation including a QA project plan and a written sampling plan. These documents will either be current WIPP plans or new plans developed specifically for SWMU sampling activities (see WP 02-EC.05).

\subsubsection{Selecting Sampling and Field Measurements Locations}

Appropriate sampling locations will be based on previous sampling and analysis results from the VRA. Sample locations will be selected to allow the extent of contamination to be more carefully defined. The sample depths will be consistent with sample depths used for the VRA. 


\subsubsection{Number of Sampling and Field Measurement Sites}

If it is determined that further sampling is required, samples will be collected from the SWMUs and AOCs so as to determine the extent of contamination. As previously stated in Section 2.1.1, the large amount of analytical, technical, and risk information associated with previous sampling and analysis efforts has determined that a biased, judgmental sampling approach, rather than statistical one, is appropriate.

\subsubsection{Sampling Conditions}

Only soil samples will be collected from the SWMUs and AOCs. The only additional field measurements anticipated are defining the locations of the soil samples (e.g., horizontal and vertical location). In general, only adverse weather conditions (i.e., rain, high winds) will restrict soil sample collection.

\subsubsection{Measurement Parameters}

The measurement parameters will include sample location, sample depth, and four inorganic constituent concentrations (i.e., barium, chromium, lead, and nickel). The constituents selected for each SWMU are based on the NMED Technical Support Document (NMED, 1999b) and the results of the VRA sampling.

\subsubsection{Frequency of Sampling, and Length of Sampling Period}

Only one round of sampling is anticipated for each SWMU. The length of each sampling day will encompass a single work shift for the sampling team. In addition, it is anticipated that the sampling will be completed within 20 workdays.

\subsubsection{Types and Number of Samples}

Soil investigative samples were collected using a direct push methodology. This method uses a truck-mounted sampling device. Soil is collected in a lined, stainless steel cylinder that is pushed through soil to the desired depth using a hydraulic ram. For the planned soil samples, Teflon ${ }^{\circledR}$ liners will be used in the direct push cylinder. Because soil samples were collected using the direct push methodology, glass sample containers (cylinder liners) cannot be used. After sample collection, the samples were placed in sample coolers, pending shipment to the laboratory. Quality control samples (i.e., rinseate) will be also collected during future SWMU sampling activities. The number of samples collected will ensure adequate delineation of the extent of contamination, if any.

\subsubsection{Procedures to Prevent Contamination}

Field sampling procedures to prevent contamination of sampling or field measurements equipment and cross-contamination between sampling points include using a separate Teflon ${ }^{\circledR}$ liner for each sample and decontaminating the sampling equipment after collecting each sample. These procedures are consistent with sampling procedures 
recommended by the EPA. Current procedures used at the WIPP site are documented in WP 02-EC.05 and the WIPP Site Effluent and Hazardous Materials Sampling Plan (WP 02-EC.06).

\subsubsection{Sampling Operations and Procedures}

Field documentation protocols for sampling operations for the SWMUs are consistent with EPA guidance. Current procedures used at the WIPP site are documented in WP 02-EC.05 and WP 02-EC.06. These documents provide methods for the following:

- $\quad$ Sample collection

- $\quad$ Sampling equipment decontamination

- $\quad$ Field documentation practices

- $\quad$ Sample chain of custody

- $\quad$ Sample containers, preservation, and holding times

- $\quad$ Sample classification, handling, and shipping

Specific procedures and requirements for SWMU sampling activities are included in applicable existing WIPP sampling plans.

\subsubsection{Selecting Appropriate Sampling Containers}

Samples are collected using a direct push methodology (forcing a sampling device constructed of stainless steel to the desired sampling depth using a hydraulic ram [e.g., ASTM D1587-94 Standard Practice for Thin-Walled Tube Geotechnical Sampling of Soils]). The direct push methodology uses a clean Teflon ${ }^{\circledR}$ liner for each sample.

The portions of each liner containing the sample selected for analysis will be sealed and sent to the laboratory. The use of the clean Teflon ${ }^{\circledR}$ liner for each sample minimizes sample handling. Prior to analysis of soil for metals, the laboratory will homogenize the soil from the liner in each sampling interval to obtain a representative sample. Current sampling procedures used at the WIPP site are documented in WP 02-EC.05 and WP 02-EC.06.

\subsubsection{Preserving Samples}

For soil samples, no chemical preservatives were used. Samples were cooled to four degrees centigrade after collection and during shipping and storage. Aqueous rinseate samples were collected to assure decontamination of probe equipment. These samples were not acidified. They were cooled to four degrees centigrade after collection and temperature was maintained during shipping and storage. Procedures for preserving samples are consistent with EPA guidance. Current procedures used at the WIPP site are documented in WP 02-EC.05 and WP 02-EC.06. The analytical methods and subcontractor laboratory SOPs for the sample analyses are used to define any additional or alternative sample preservation requirements. 


\subsubsection{Controlling Chain of Custody}

Procedures for controlling $\mathrm{COC}$ are consistent with EPA guidance. Current procedures used at the WIPP site are documented in WP 02-EC.05 and WP 02-EC.06. The subcontractor laboratory SOPs for the sample analyses are used to define procedures for controlling $\mathrm{COC}$ in the laboratory.

\subsubsection{Disposing of Contaminated Materials Generated by Activities}

Based on historical sampling performed at the SWMUs and on previous analyses of SWMU materials for toxicity using the Toxicity Characteristic Leaching Procedure (TCLP) as part of the WIPP VRA, the SWMUs do not contain material that exhibits the characteristic of toxicity. Based on the TCLP results and the regulatory definition of a hazardous waste, the material in the SWMUs is not hazardous waste. Therefore, no hazardous waste contaminated materials (i.e., personal protective equipment (PPE), gloves, or decontamination water) are expected to be generated by the SWMU sampling activities. Soil cuttings, if any, generated during the sampling activities will be left at the sampling location.

Sampling equipment is decontaminated between sample locations to prevent crosscontamination of samples. Equipment rinse water will be collected and managed until the analyses of the samples determine the appropriate disposition.

\subsection{Sample Analysis}

For a RCRA site such as WIPP, Test Methods for Evaluating Solid Wastes, Physical/Chemical Methods (EPA-SW-846), (EPA, 1997b) are appropriate. Contract Laboratory Program (CLP) analytical method criteria are appropriate for analysis of samples from Comprehensive Environmental Response, Compensation, and Liability Act sites. The use of the EPA's CLP analytical methods would be inappropriate at the WIPP SWMUs and are in direct conflict with Permit requirements for WIPP. Section VII.M.2.d of the Permit requires that the SAP and reported data be consistent with EPA RCRA guidance including SW-846. Further, soil samples collected during previous site investigations were analyzed using SW-846 methods. To ensure comparability with previous investigations, analyses of collected soil samples were performed using SW-846 methods.

A subcontract analytical laboratory approved by the Permittees shall perform laboratory sample analyses in support of sampling activities. The analytical program is consistent with EPA guidance. Sample analyses are performed in accordance with the general requirements and procedures set forth in WP 02-EC.05. The specific target analytical parameters and the field and laboratory analytical methods to be applied during SWMU sampling activities are described in ACAA planning documents. Laboratory analytical methods for SWMU sampling activities are based on standard reference methods from SW-846. The subcontract laboratories shall develop and maintain a set of written instructions, or SOPs, for performance of the reference methods. Each method SOP cites the specific reference method on which it is based (e.g., EPA Method 6010B for 
inorganic compounds). The SOPs for the laboratory analytical methods to be applied in support of the SWMU sampling activities are approved by the SWMU Project Manager for consistency with EPA method requirements and with program QA/QC objectives.

Standard operating procedures will include the following information:

- $\quad$ COC procedures

- $\quad$ Sample storage procedures and holding times

- $\quad$ Sample preparation methods

- $\quad$ Analytical procedures

- $\quad$ Calibration procedures and frequency

- $\quad$ Data reduction, validation and reporting

- $\quad$ Frequency of internal QC checks and laboratory performance audits

\subsubsection{Chain-of-Custody Procedures}

The subcontractor laboratory SOPs for COC during sampling, shipment, handling, and analysis will be maintained on file. Chain-of-custody procedures have been established at WIPP to assure that samples are always under the control of responsible individuals who can maintain sample integrity.

\subsubsection{Sample Storage Procedures and Holding Times}

Procedures for sample storage and holding times are consistent with other procedures that have been established at the WIPP site, and with the analytical methods. The WIPP procedures are documented in WP 02-EC.05 and WP 02-EC.06. The subcontractor laboratory SOPs for laboratory sample storage and holding times are maintained on file.

\subsubsection{Sample Preparation Methods}

Analytical methods for sample analyses are specified in the ACAA planning documents. The laboratory SOPs for laboratory sample preparation are maintained on file.

\subsubsection{Analytical Procedures}

The methods for sample analyses are specified in the ACAA planning documents. The laboratory SOPs for laboratory sample analysis are maintained on file.

\subsubsection{Calibration Procedures and Frequency}

The methods for sample analyses are specified in the ACAA planning documents. The laboratory SOPs for laboratory sample analysis, including calibration procedures and frequency, are maintained on file. 


\subsubsection{Data Reduction, Validation, and Reporting}

General considerations for data reduction, validation, and reporting are provided below. Additional details for these activities will be specified in the ACAA planning documents.

\subsubsection{Data Reduction}

Data reduction includes summarizing collected data and performing mathematical or statistical analyses. The subcontractor laboratory reduced analytical data and provided the analytical data in an electronic format specified by the Permittees. The SWMU Project Manager or designee amends the electronic data file to include the fieldgenerated data and data qualifications. Analytical results and selected field measurements have been entered into the project database system described in Section 4.0 of the FWP. Additional details for data reduction have been specified in the ACAA planning documents.

\subsubsection{Data Validation}

Technical data, including field measurements and results of field sample analyses, have been reviewed and validated according to internal QA procedures to monitor the performance of each task. Laboratory analytical data was validated according to method-specific SOPs and, where applicable, using methods consistent with the EPA Contract Laboratory Program National Functional Guidelines for Organics/Inorganics Data Review (EPA, 1994c, 1999a, 1999b, 1999c). The Functional Guidelines for Organics/Inorganics Data Review are the primary EPA reference for data validation and contain the most comprehensive data validation procedures available. Although these guidelines were developed for the CLP, application of these data validation procedures, as described in the Functional Guidelines for Organics/Inorganics Data Review, is appropriate for the EPA SW-846 analytical methods and is used for analyses of samples collected from the SWMUs. Consequently, the applicable portions of these procedures were used to validate SW-846 analytical data. Data collection and QA procedures for validating field measurements and laboratory data are described below.

\section{Field Measurement Data Validation Procedures}

Field measurement data validation procedures include reviewing the raw data and supporting documentation generated from field investigations. Validation of field data was performed by the SWMU Project Manager or designated representative. Data validation was performed to meet the project's intended data uses by checking the procedures used in the field and comparing the data to previous measurements. The following areas may be addressed during validation:

- Documentation of field observations

- $\quad$ Documentation of field procedures

- $\quad$ Sampling methodology

- Sample technical holding times and preservation

- Sample custody documentation and labeling 


$\begin{array}{ll}\text { - } & \text { Instrument selection and use } \\ \text { - } & \text { Instrument calibration and standardization } \\ \text { - } & \text { Instrument preventive maintenance } \\ \text { - } & \text { Field QC checks, if applicable } \\ \text { - } & \text { Field deviations } \\ \text { - } & \text { Field data completeness } \\ & \text { Sampling limitations }\end{array}$

Analytical Data Validation

The analytical laboratory participated in applicable EPA and/or other regulatory approval programs to assure that analytical, QA/QC, and data reporting protocols are consistent with the project DQOs, and with general EPA data quality guidelines (EPA, 1994a). In general, definitive data produced by standard EPA methods for the determination of target analytes (e.g., EPA SW-846 methods) were validated in a manner consistent with EPA Functional Guidelines for Evaluating Organic and Inorganic Analyses (EPA, 1994c, 1999a, 1999b, 1999c). Where EPA functional guidelines do not apply, the analytical data will be validated in accordance with the appropriate method SOPs and project control criteria. Features of the internal and external data validation programs are summarized below.

- Internal Laboratory Data Validation: Under the direction of the laboratory QA manager, the laboratory will review analytical data to insure that results for investigative and QC samples meet EPA functional guidelines or methodspecified criteria. Laboratory review of analytical data will be performed in accordance with the Laboratory QA Plan and supporting SOPs and EPA guidance document SW-846 (EPA, 1997b). For target analytes that do not have QC criteria specified in EPA guidance documents, QC criteria will be based on laboratory method-specific data.

- $\quad$ External Laboratory Data Validation Procedures: Definitive laboratory analytical data used for program decisions will be reviewed by the SWMU Project Manager or designated representative to independently validate the laboratory results. Validation efforts will include review of the QC summary report submitted by the laboratory or may require review of the raw data provided by the laboratory. At a minimum, the reported analytical data will be reviewed for completeness and compliance with appropriate QC criteria. If problems with the analyses are found during the review that may affect the analytical results, the analytical data will undergo an additional raw data review and calculation check. The laboratory analytical data will be validated according to method-specific SOPs and/or the EPA's Laboratory Data Validation Functional Guidelines for Organics/Inorganics Analyses (EPA, 1994c, 1999a, 1999b, 1999c). Where EPA QC limits are not available, laboratory-generated QC limits will be used. 
Based on a comparison of the data with established QC limits, qualifiers are applied to the data as necessary to document the utility of reported results. Data qualifiers and definitions, consistent with method-specific SOPs and/or EPA functional guidelines, will be used where appropriate in validation. Data qualifiers are attached to the tabulated final analytical data to indicate the data quality relative to intended data use. The qualifiers are attached to the data whenever they appear in hard copy or computerized form to assure that data users are aware of the quality and limitations of the data. Upon completion of data validation, validation summary reports will be placed with the original laboratory report packages in the project file.

Additional qualifiers may be added to the data at the discretion and approval of the SWMU Project Manager. When additional qualifiers are added to the data, a complete explanation of the qualifiers will accompany the data review.

\subsubsection{Data Reporting}

Results of field sampling and analytical results will be included in the final No Further Action Request. The report will be prepared and distributed according to the requirements of the Permit. The report will describe both the field activities performed and the results for collected data. This report, to the extent possible, will include the following:

- $\quad$ Presentation of results
- $\quad$ Lummaries of field data from field measurements
QA/QC data

Project files contain the following documents for each sampling event:

- $\quad$ Field measurements and logbooks

- Laboratory data packages, including, but not limited to, COC records, copies of sample tracking records, analysts' logbook pages, instrument logbook pages (including instrument conditions), bench sheets, instrument readout records, computer printouts, chromatographic charts, raw data summaries, correspondence and memorandums, and document inventory

- Data validation reports summarizing the validation process used and specific comments pertaining to a sample or group of samples

Additional details for data reporting will be specified in the ACAA planning documents. 


\subsubsection{Frequency of Internal Quality Control Checks and Laboratory Performance Audits}

The type and frequency of internal QC checks and the approach for evaluating these checks relative to project $\mathrm{DQO}$ and data use objectives are documented in the selected subcontractor laboratory SOP and are specified in the ACAA planning documents.

Depending on the data collection activity, internal QA checks could include the following:

- $\quad$ Field-related blanks such as rinseate and trip blanks, as appropriate

- $\quad$ Field duplicates

- $\quad$ Matrix spike/matrix spike duplicates (MS/MSDs)

- $\quad$ Standard analytical reference materials and audit samples

- $\quad$ Confirmation samples (sent to alternate laboratories)

In addition to these project QC checks, standard internal laboratory QC checks are required (e.g., calibration checks, surrogate spikes, blanks, laboratory duplicates, laboratory control samples).

At this time, the Permittees are not considering performing a separate performance audit of the selected subcontractor laboratory.

\subsection{DATA MANAGEMENT PLAN}

This section of the FWP describes the general data management practices implemented at the WIPP site to document and track investigation data and results. This Data Management Plan includes a discussion of the expected data types to be generated during future investigations, if required: electronic data management procedures (including tabulated and map data storage), database interfaces, hard-copy data management procedures; data management responsibilities; and data flow. Data management practices will be based on the WIPP Records Management Program (WP 15-PR) and WP 13-1.

\subsection{Data Documentation Materials and Procedures}

Data documentation materials generated during future investigations (if required) will include field and laboratory notebooks, forms, and supporting information. This section discusses how each type of data is transferred into the project files.

Primary responsibility for data management activities under the SAP will reside with the SWMU Project Manager. The SWMU Project Manager will designate other individuals from EC or other facility organizations that will have access to the data and assist with data management activities. Additional QA oversight of data management activities will be performed by the QA Department. 


\subsubsection{Field Data}

WIPP field personnel will complete COCs for samples collected. The original copy of the COC will be shipped with the samples, one copy will be provided to the SWMU Project Manager for sample tracking entry, and one copy will be retained in the files of the Sampling Team. The laboratory will also be required to maintain signed COCs and the bill of lading used to ship the samples to the laboratory. This information will be returned to the Permittees in the analytical data packages.

Other field documentation, including field notes and sampling data sheets, will be reviewed for correct formatting, completeness, and accuracy of the information reported. Designated WIPP personnel will submit these documents to the SWMU Project Manager for entry of appropriate information into the database management system. After data entry is complete, the original field documents and a listing of the data entered in the database will be sent to the appropriate technical staff for review and approval. The original field documents and printouts of the entered data will then be filed in the project files.

\subsubsection{Analytical Data}

During sample analysis at the laboratory, analytical results will be either entered into the laboratory information management system (LIMS) or directly downloaded from the analytical instrument. The data will be reviewed in the laboratory for errors or omissions to ensure that the data are reported in the correct format. Upon completion of these efforts, the laboratory will submit electronic data deliverables and hard-copy raw data to the Permittees. Designated WIPP personnel will translate the electronic data into the proper database format (if necessary), check for incorrect information, and load the data into the database management system. The SWMU Project Manager will be notified of inconsistencies, omissions, or errors with the electronic data deliverables that require correction. The SWMU Project Manager will notify and work with the laboratory to correct the identified problems.

\subsection{Project File Requirements}

The project files and records will be controlled and maintained in accordance with WP 15-PR. Complete, accurate, and auditable project records will be maintained. Quality assurance records are identified in the project-specific plans and procedures. As applicable, the use and management of the software and electronic data utilized complies with the QA and documentation requirements established in WP 13-1.

\subsection{Project-Related Progress Reporting Procedures and Documents}

Once final data are checked, data users will be able to query the database, organize the data, perform numerical analysis, and produce hard-copy output for data interpretation and reporting. Possible output from the data management system could include the following: 
- Tabular data: Tables of analytical results, statistical result summaries, summaries of samples collected and analyses performed, geologic and lithologic data tables, tables of risk-based screening criteria or risk assessment data.

- $\quad$ Graphical (map) data: SWMU location maps, sample location maps, boring logs, geologic cross sections, SWMU maps depicting the distributions of specific target constituents, site conceptual models, design drawings for corrective actions.

Output from the data management system will be used to develop routine progress reports and project-specific reports for submittal according to Permit requirements.

\subsection{Data Records}

Possible data collection in the future, if required, includes:

- $\quad$ Soil sampling and analysis

- $\quad$ QC sample collection and analysis

- Identification of sample locations

The data record for each sample and field measurement will include at least the following information: unique measurement code, measurement location, measurement type, laboratory identification number, property or component analyzed, and results of analysis. Data and documentation are expected to be compiled and processed in electronic and hard-copy forms.

\subsubsection{Electronic Data}

Electronic data can be divided into two categories: data tables and graphical (map) data. Data will be managed using a database management system that provides an effective framework to handle the existing and anticipated data. In addition to meeting the needs of data users, the database management system may incorporate the following capabilities:

- $\quad$ Store tabular data (such as analytical results, data qualifiers, and boring log data)

- $\quad$ Store graphical data map data (such as cultural features, sample location, and other spatial features) using appropriate graphical software (such as AutoCAD), or in a spatial database (commonly referred to as a Geographic Information System [GIS])

\subsubsection{Tables}

Tabular data include data formatted as rows and columns and stored in tables of an electronic spreadsheet or relational database. Tabular data will include raw data, data 
sorted by significant features (e.g., location, media, constituent), data reduction for statistical analysis, and summary data.

Given the possible field activities discussed above, the following types of electronic tabular data may be generated or processed:

- $\quad$ Sample identification information

- $\quad$ Analytical data

- $\quad$ Soil boring data

- $\quad$ Sample location/survey data

- $\quad$ Analytical results

- $\quad$ Numerical analysis results (e.g., statistics)

Electronic data in tabulated format will be stored and retrieved through a spreadsheet program or a relational database program.

\subsubsection{Graphical Formats}

Graphical formats for data presentation include both summaries of results and map data. Sampling, analytical, and numerical results may be presented in bar graphs, line graphs, and other data presentations and be stored with the tabular data. Map data are information more appropriately stored in a graphical format than in a tabular format. Storage of the following types of electronic map data is possible:

- $\quad$ Plan maps

- Isopleth plots

- $\quad$ Cross sections

- Three-dimensional displays

- $\quad$ Sampling locations and grid

- $\quad$ Levels of contamination at each sampling location

- Geographical extent of contamination

- $\quad$ Changes in concentration relative to source, time, depth, and other parameters

- $\quad$ Cultural features (e.g., roads)

If necessary, electronic data of mapped features will be stored as appropriate graphical data or in a spatial database format.

\subsubsection{Hard-Copy Data}

Hard-copy data are generated during investigation activities to document the work that was performed. Additional hard-copy data will be generated from the electronic data described above. Examples of hard-copy data include field notes, boring logs, COC forms, and analytical data packages. Section 4.2 of this plan discusses the procedures that will be used to store hard-copy data, which will be based on facility record management requirements. In addition to filing the hard-copy forms in the project files, information will be entered from hard-copy forms into the project database when

appropriate. Many documents are gathered, transferred, and generated during the RFI 
investigations. The term "document" refers to relevant information in hard-copy form (i.e., plans, reports, correspondence, raw and validated analytical data, field notes, maps, figures, models, etc.). Documents gathered or generated are stored in a central project file administered by the SWMU Project Manager in accordance with WP 15-PR.

\subsection{Sample Tracking}

A reliable sample tracking system is essential to assure the maintenance of environmental data integrity. Environmental samples are tracked using a sample tracking database in combination with a filing system. The effectiveness of the system will be verified through periodic audits. Audits of the database records include tracking of data collected during field activities and a review of the data stored in the database. These audits, conducted by the SWMU Project Manager, or designated representative, will consist of following the flow of a portion of data completely through the hard-copy and electronic systems. In addition, a small portion of the data in the database will be periodically checked against original information. Access to the sample tracking database is limited to the SWMU Project Manager and designated personnel, who are responsible for sample tracking. The sample tracking database will consist of a table within the general electronic database and will include fields such as:

$\begin{array}{ll}\text { - } & \text { Sample identification } \\ \text { - } & \text { Container } \\ \text { - } & \text { Sample volume } \\ \text { - } & \text { Sample matrix } \\ \text { - } & \text { Analysis requested } \\ \text { - } & \text { Sample date } \\ \text { - } & \text { Date data received } \\ \text { - } & \text { Date data validated/reviewed } \\ & \text { Datectronic data QC check }\end{array}$

Using the sample tracking database, the SWMU Project Manager or designee will track sample progress through sampling and analysis; log in data received from the field or subcontractor laboratories; check that COCs and hard-copy data have been filed; resolve data discrepancies with the laboratory; and transfer approved data to data users and reviewers. Data gaps will be identified, and the resolution of the data gaps will be documented.

\subsection{SITE SAFETY AND HEALTH PLAN}

Section VII.U.3.h of the Permit requires that the site safety and health plan for the facility include the following:

a. A description of the facility including availability of resources such as roads, water supply, electricity, and telephone service 
b. A description of the known hazards and evaluation of the risks associated with each activity conducted, including but not limited to on- and off-site exposure to contaminants during implementation of interim measures

c. A list of key personnel and alternatives responsible for site safety, response operations, and protection of public health

d. A delineation of the work area

e. A description of levels of protection to be worn by personnel in the work area

f. Procedures established to control site access

g. Decontamination procedures for personnel and equipment

h. Site emergency procedures

i. Emergency medical care procedures for injuries and toxicological problems

j. Requirements for an environmental field monitoring program

k. Routine and special training requirements for responders

I. Procedures for protecting workers from weather-related problems

Each of these items is described in the following subsections.

\subsection{Facility Description}

The WIPP facility provides surface structures to accommodate personnel, equipment, and support services. These surface structures serve the operational functions of the WIPP and are available to support site activities. The surface facilities are located in the Property Protection Area of approximately 34 acres within the perimeter fence. The principal surface structure is the Waste Handling Building; other surface structures include hoist houses, the Support Building, the Guard and Security Building, office trailers, the Exhaust Filter Building, warehouses and shops, the Water Pump House, the Training Building, the Engineering Building, the Core Storage Building, and the Safety and Emergency Services Building.

Access to the WIPP facility is provided by two access roads that connect with U.S. Highway 62/180, 13 miles to the north, and NM Highway 128 (Jal Highway), 4 miles to the south. The north access road, which connects the site to U.S. Highway $62 / 180$, was built specifically for the DOE. The south access road is a county highway maintained by Eddy County. Rail access is from the west across the south access road. Access to the facility for personnel, visitors, and vehicles is provided through a security checkpoint (vehicle trap). Numerous graded roads are available throughout the WIPP site. These are generally single lane, packed caliche roads. They are used to 
access remote areas of the site for the purposes of monitoring. These roads are adequate to handle the heaviest equipment that is anticipated for use during site activities.

The primary function of the WIPP facility water system is to supply water for domestic use and fire protection. The Double Eagle Water Company, owned by the city of Carlsbad, furnishes water. Wells located 30 miles north of the WIPP facility are the source of the water. Water is supplied by gravity flow through a 24-inch diameter pipeline to a junction point about 13 miles north of the site at U.S. Highway 62/180. This line is sized to provide 6,000 gallons per minute for use by others, in addition to the peak flow rate required by the WIPP facility. Controls at the junction point give the WIPP facility priority over flows to all other users. A 10-inch diameter pipeline supplies water by gravity flow from the tie-in point to the WIPP facility.

At the WIPP facility, the water enters a pair of 180,000-gallon, aboveground storage tanks located adjacent to the pump house. These tanks are 32 feet in diameter and are constructed of welded steel. The water level in each tank is monitored in the Central Monitoring Room (CMR). Of the 360,000-gallon total capacity, about 160,000 gallons (80,000 gallons per tank) are designated for storage of a two-day supply of domestic water. At least 180,000 gallons of the remaining 200,000 gallons of water are dedicated to fire suppression and are sufficient to handle the maximum credible fire. Separate sets of pumps for the domestic water and fire-water systems are provided in the pump house. During a fire, the pump is started, and available fire water is used. The primary fire-water pump is a 100 percent capacity electric pump. A 100 percent capacity diesel fire-water pump provides backup in case of a power failure or when maintenance is required on the electric pump. Each fire-water pump is rated at 1,500 gallons per minute at 125 pounds per square inch.

Electricity is purchased from a local utility and is delivered to the WIPP site via a power line that feeds from both the north and the south. In the event that normal utility power is lost, on-site diesel generators will provide alternating current (AC) power to important WIPP facility electrical loads. Uninterruptible power supply (UPS) units are also on-line, providing power to important monitoring systems.

In case of a loss of utility power, backup power to predetermined loads can be supplied by either of the two on-site diesel generators. Each of these units provides 480 volts (V) of power with a high degree of reliability and is sized to feed the selected loads. The diesel generators can be brought on-line within 30 minutes.

The intraplant communication system is designed to provide day-to-day communication and immediate emergency instructions to facility personnel. It includes two-way communication by the public address (PA) system and its intercom phones and paging channels, a telephone system, mine phones, pagers and plectrons, portable two-way radios, and local and facility-wide alarm systems.

The intercom system (with an integral PA system) consists of handset stations and loudspeaker assemblies, with multiple amplifiers. The system has multiple channels in 
the main buildings. Initial communication between parties within the plant can be established by using the paging channel. Each designated location has a single set of electrically isolated speakers and a handset. In order to cover most areas in the plan, loudspeakers are properly oriented, and volume levels are adjusted. If one station fails, the remaining stations are isolated from the out-of-service unit to prevent a failure in the remaining system.

Private branch automatic exchange two-way communication is provided between any two telephones located above or below ground. Direct dialing to outside telephones and direct dialing to WIPP facility telephones are provided by this system. Failure of a single telephone station does not affect the balance of the telephone system. If the telephone system should fail, the PA system, the plectrons, and the portable two-way radios provide backup surface communications.

The Site Notification System (SNS) consists of pagers in the possession of office wardens and plectrons located in various buildings. The SNS pagers and plectrons are tone-activated radio receivers that are activated by the two-way radio system. To generate a tone on the pagers and plectrons or to send a verbal message, the radio operator enters a security code into the two-way radio system and begins broadcasting. The SNS pagers are portable and battery-operated. The plectrons are portable and can be plugged into a standard electrical circuit or powered from internal batteries that are continuously recharged when connected to the electrical circuit.

A plant radio station in the Guard and Security Building, one located in the Emergency Operations Center in the Safety and Emergency Services Building, and one in the CMR, allow two-way radio communication with on-site personnel and with mobile/portable WIPP facility radios operating on and off the WIPP site. The two-way radio also allows one-way emergency notification on the portable SNS pagers and plectrons. The twoway radio system located in the CMR is supplied with power from the UPS if the off-site power supply fails.

\subsection{Description of Known Hazards and Evaluation of Risks}

Prior to any work being performed, a job hazard analysis (JHA) will be performed to evaluate known hazards and risks associated with each activity. The JHAs are prepared to assure that any hazardous work (not already covered by a procedure) is performed with due precaution. The job manager, with input from personnel conducting the work, completes the JHA, detailing the work description, specific hazards involved, and mitigating actions required. The personnel review the form, check on the adequacy of the mitigating actions and, if sufficient, approve the JHA.

Safety assessments were completed during the Voluntary Release Assessment Program (DOE/WIPP 96-2209) and no chemical safety concerns were identified. No off-site exposure to contaminants during implementation of interim measures is anticipated, because no interim measures have been identified. 


\subsection{Key Personnel}

A number of WIPP personnel will be involved in performing future SWMU sampling activities if required. The SWMU Project Manager will be responsible for coordinating sampling activities. The SWMU Project Manager will marshal and monitor needed resources for the program and serve as liaison between other cognizant organizations. The SWMU Project Manager will report to the DOE through the ES\&H manager.

Other organizations that may be involved in SWMU sampling activities include the Sampling Team, Industrial Safety and Hygiene, and subcontractors. The actual involvement of these organizations and their direct responsibilities will be solicited as needed by the SWMU Project Manager. Responsible organizations and individuals will be specified as part of the ACAA planning documents.

\subsection{Delineation of Work Area}

The work areas for the investigation at each SWMU and AOC will be specified in the ACAA planning documents and will consist of the physical dimensions of the SWMUs and the area immediately surrounding the SWMUs to be investigated. Samples of soil will be collected at discrete locations within and near the SWMUs and AOCs. The sampling team leader has been responsible for identifying sampling locations and identifying any necessary exclusion areas for personnel.

\subsection{Levels of Personnel Protection}

The Industrial Safety and Health Section provides assistance in defining hazards associated with particular activities and in defining appropriate safety precautions and PPE for specific job assignments. As a result of safety assessments completed during the Voluntary Release Assessment Program (DOE/WIPP 96-2209) no chemical safety concerns have been identified. For anticipated activities at the SWMUs and AOCs, Level D PPE will be used (i.e., steel toe boots, safety glasses, work gloves, and hard hat, if appropriate).

\subsection{Procedures for Site Access Control}

Attachment $\mathrm{C}$ of the WIPP Permit defines site access and security procedures. For each SWMU and AOC sampled, the sampling team leader will be responsible for restricting access to the sampling locations.

\subsection{Decontamination Procedures for Personnel and Equipment}

Based on safety assessments completed during the Voluntary Release Assessment Program (DOE/WIPP 96-2209), no chemical safety concerns have been identified that suggest that personnel decontamination procedures will be required. Equipment decontamination procedures will be initiated to prevent cross contamination between samples (see Section 3.2.7 of this FWP). 


\subsection{Site Emergency Procedures}

Attachment $F$ of the WIPP Permit (the RCRA Contingency Plan) and the WIPP Emergency Management Plan describe site emergency procedures. If ACAA planning indicates that these procedures are not adequate, additional procedures will be identified.

\subsection{Emergency Medical Care Procedures}

Attachment $F$ of the WIPP Permit and the WIPP Emergency Management Plan describe site emergency medical care procedures. If ACAA planning indicates that these procedures are not adequate, additional procedures will be identified. In addition, the General Employee Training for the site describes emergency medical care procedures.

\subsection{Environmental Field Monitoring Program}

No environmental field monitoring program is anticipated for future SWMU sampling activities. These activities will be restricted to collecting soil samples. No personnel exposure to other constituents is anticipated.

\subsection{Routine and Special Training Requirements for Responders}

At WIPP, responders require Hazardous Waste Worker and Hazardous Waste Responder training. No special training requirements are anticipated for future SWMU sampling activities.

\subsection{Procedures for Protecting Workers from Weather-Related Problems}

Prior to SWMU sampling activities, sampling personnel will sign out from their designated work locations to indicate that they are at the sampling location. The sampling team leader will receive a cellular telephone, a pager, or a portable radio, whichever is most efficient for communication and notification. In the event that site personnel identify weather-related problems, this information can be transmitted to the sampling team. If the sampling team identifies weather-related problems, the information can be transmitted to site personnel. In either case, sampling personnel will take appropriate shelter in the field, or return to their work locations.

\subsection{Additional Considerations}

Procedures for delineating the activity work area, decontamination procedures, and requirements for environmental monitoring programs and other safety-related issues potentially applicable to future SWMU sampling activities as required by the Permit are contained in the following WTS documents:

- $\quad$ Quality Assurance Project Plan for WIPP Site Effluent and Hazardous Materials Sampling (WP 02-EC.05) 
- WIPP Site Effluent and Hazardous Materials Sampling Plan (WP 02-EC.06)

- $\quad$ WIPP Chemical Hygiene Plan (WP 12-IH.01)

- $\quad$ WIPP Industrial Hygiene Program (WP 12-IH.02)

- Industrial Safety Program (WP 12-IS.01)

- $\quad$ Fire Prevention Program (WP 12-FP.01)

Applicable requirements from these documents necessary for the investigations will be included in the ACAA planning documents. In addition, the specific information required by Permit Condition VII.U.3.h (1) will be included in the ACAA planning documents. The SWMU Project Manager will verify that appropriate health and safety activities are coordinated with other organizations and incorporated into the investigations.

\subsection{Consistency with Other Programs}

At the WIPP site, safety is each individual's responsibility. The facility has an exemplary safety culture. As required by Permit condition VII.U.3.h.(2), the safety and health program in place at WIPP is consistent with DOE, National Institute for Occupational Safety and Health, Occupational Safety and Health Administration, Mine Safety and Health Administration, and EPA requirements, and state and local regulations.

\subsection{COMMUNITY RELATIONS PLAN}

This community relations plan addresses issues relevant to the public regarding dissemination of information on future investigation activities and results for the SWMUs and AOCs. Section VII.U.3.i of the Permit includes the following requirements for community relations:

- Obtain an initial facility mailing list of interested persons and entities from the NMED and update it semiannually.

- Hold informal meetings, briefings, and workshops as appropriate with the public and local officials.

- $\quad$ Prepare and disseminate news releases and fact sheets, and ensure that approved work plans, reports, Special Permit Conditions Reports, and quarterly progress reports are available to the public.

- $\quad$ Create public information repositories and reading rooms.

- Update materials in the repositories and reading rooms as appropriate.

- $\quad$ Prepare quarterly technical progress reports for the NMED. 
Establish procedures for immediate notification of affected persons or entities which could be impacted by newly discovered off-site releases from the SWMUs and AOCs.

\subsection{Facility Mailing List}

The initial facility mailing list was obtained from the NMED on December 17, 1999. Additions deletions to this list are provided by the NMED prior to each mailing. Likewise, any NMED updates to the mailing list are requested prior to each mailing. Formal notification of changes to the mailing list are made in accordance with the permit.

\subsection{Informal Meetings}

Informal meetings, including briefings and workshops as appropriate, will be held with the public and local officials before and during the RFI process if requested by the public or the NMED. These meetings will be used for discussing activities associated with the ACAA activities and the report of investigative activities.

\subsection{News Releases, Fact Sheets, Approved RFI Work Plans, RFI Reports, Special Permit Conditions Reports, and Quarterly Progress Reports}

If requested by the NMED, the Permittees will prepare news releases and fact sheets describing the availability of approved reports, special permit condition reports, and publicly available quarterly progress reports that explain the progress and conclusions of field investigation activities. At this time, the Permittees will notify each individual on the mailing list regarding the availability of documents required by the Permit.

The Permittees public affairs organizations will assist in preparation and dissemination of required news releases, as well as responses to news media and public inquiries.

\subsection{Information Repositories}

As required by the Permit (VII.D, and VII.U.3.i.[4]), the DOE has established information repositories in Santa Fe (New Mexico State Library), Albuquerque (University of New Mexico Zimmerman Library), and in Carlsbad (Skeen-Whitlock Building).

A notice, approved by the NMED, was sent to all individuals on the list December 21, 1999, describing the location, purpose and contents of the information repositories. In addition, the notice described the schedule for submitting written comments to the NMED regarding documents placed in the repositories. As required by the Permit, these activities were completed within 30 days of the effective date of the Permit (November 26, 1999).

In the future, deliverables and correspondence produced as part of the ACAA activities will be placed in the repositories on or before the date due to the NMED. These documents may include approved work plans, technical reports, and progress reports. 
At least five days before each submittal is due to the NMED and placed in the repository, a written notice will be mailed to each individual on the current facility mailing list describing the submittal and indicating the date the submittal will be available for review at the repositories.

\subsection{Updates of Materials in the Information Repositories and Reading Rooms}

To the extent necessary, the Permittees will update materials in the information repositories. Routine updates will occur as Permit required documents are completed and submitted to the repositories.

\subsection{Quarterly Technical Progress Reports}

Quarterly technical progress reports will be prepared and submitted to the NMED and placed in the Information Repositories regarding the ACAA activities in accordance with Section VII.I (and VII.U.3.i.[6]) of the Permit.

\subsection{Immediate Notifications}

Although it is unlikely that newly discovered off-site releases will be identified from these SWMUs, plans exist for immediate notification to nearby residents of such releases. The RCRA Contingency Plan, contained in Attachment F of the Permit, identifies the WIPP incident response personnel and responsibilities and the plans and procedures for notifications of site-related incidents. To the extent necessary, the requirements of the RCRA Contingency Plan will be included in the ACAA planning documents for community relations.

\subsection{REFERENCES}

40 CFR 260-270: Environmental Protection Agency (EPA) Regulations Implementing the Resource Conservation and Recovery Act (RCRA), codified by New Mexico as 20.4-1, 100 to 900 New Mexico Administrative Code

U.S. Congress, 1992. Public Law 102-579, Waste Isolation Pilot Plant Land Withdrawal Act. 102nd Congress, Washington, D.C. October.

New Mexico Environment Department, 1994. Assessment of Solid Waste Management Units at the Waste Isolation Pilot Plant, the WIPP RCRA Facility Assessment, (NMED/DOE/AIP 94/1), May.

New Mexico Environment Department, 1998. HRMB Standard Operating Procedures Manual, March.

New Mexico Environment Department, 1999a. Waste Isolation Pilot Plant Hazardous Waste Permit, NM4890139088-TSDF, October 27. 
New Mexico Environment Department, 1999. Technical Support Document, Exclusion/Inclusion of Solid Waste Management Units and Areas of Concern, Permit Module VII Corrective Action for Solid Waste Management Units. Waste Isolation Pilot Plant EPA No. NM4890139088. October.

New Mexico Environment Department, 2000a. Review and Comment on Facility Work Plan, Sampling and Analysis Plan, WIPP Hazardous Waste Facility Permit, EPA I.D. NM4890139088. Letter from Mr. Steve Zappe received December 6.

New Mexico Environment Department, 2000b. Technical Background Document for Development of Soil Screening Levels. Hazardous Waste Bureau and Ground Water Quality Bureau Voluntary Remediation Program, December 18.

U.S. Department of Energy, 1991. WIPP RCRA Part B Permit Application, DOE/WIPP 91-005, Revision 0.

U.S. Department of Energy, 1996. Final Voluntary Release Assessment/Corrective Action Report, DOE/WIPP 96-2209.

U.S. Department of Energy, 1997a. Supplemental Information Requested by the New Mexico Environment Department for Solid Waste Management Units, DOE/WIPP 97-2220a.

U.S. Department of Energy, 1997b. Using the Data Quality Objectives Process During the Design and Conduct of Ecological Risk Assessments, DOE/EH-0544, Washington, D.C., February.

U.S. Department of Energy, 2000. Facility Work Plan for Solid Waste Management Units and Areas of Concern, DOE/WIPP-00-2001, Rev.0, February.

U.S. Department of Energy, 2000. WIPP Sampling and Analysis Plan for Solid Waste Management Units and Areas of Concern, DOE/WIPP 00-2014, Rev. 0, May.

U.S. Environmental Protection Agency, 1983a. Interim Guidelines and Specifications for Preparing Quality Assurance Management Plans - QAMS-005/80.

U.S. Environmental Protection Agency, 1983b. Methods for Chemical Analysis of Water and Wastes, March.

U.S. Environmental Protection Agency, 1984. Guidelines Establishing Test Procedures for the Analysis of Pollutants Under the Clean Water Act. Final Rule and Proposed Rule, 40 CFR Part 136, October.

U.S. Environmental Protection Agency, 1987. Data Quality Objectives for Remedial Response Activities (Development Process): EPA/540/G-87/003, Office of Emergency and Remedial Response, Washington, D.C., March. 
U.S. Environmental Protection Agency, 1989a. RCRA Facility Investigation Guidance Document, Volumes I-IV, EPA 530/SW-89-031, May.

U.S. Environmental Protection Agency, 1989b. Risk Assessment Guidance for Superfund, Volume II, Environmental Evaluation Manual, Office of Emergency and Remedial Response, Washington, D.C., EPA/540/1-89/001.

U.S. Environmental Protection Agency, 1990. Corrective Actions for Solid Waste Management Units at Hazardous Waste Management Facilities, Proposed Rule, Federal Register, Vol. 55, No. 145, July 27, 1990.

U.S. Environmental Protection Agency, 1992. Framework for Ecological Risk Assessment. Risk Assessment Forum, Washington, D.C., EPA/630/R-92/001.

U.S. Environmental Protection Agency, 1993. Data Quality Objectives Process for Superfund, Interim Final Guidance, September, EPA 540-R-93-071.

U.S. Environmental Protection Agency, 1994a. RCRA Corrective Action Plan, Final, Office of Solid Waste and Emergency Response (OSWER), OSWER Directive 9902.3-2A, May.

U.S. Environmental Protection Agency, 1994b. Guidance for the Data Quality Objectives Process. Quality Assurance Management Staff, Washington, D.C. EPA QA/G-4.

U.S. Environmental Protection Agency, 1994c. USEPA Contract Laboratory Program National Functional Guidelines for Inorganic Data Review, EPA 540/R-94/013 February.

U.S. Environmental Protection Agency, 1996. Proposed Guidelines for Ecological Risk Assessment; Notice. Federal Register Vol. 61, No. 175, Monday September 9, 1996.

U.S. Environmental Protection Agency, 1997a. Ecological Risk Assessment Guidance for Superfund: Process for Designing and Conduction Ecological Risk Assessments, Interim Final, Environmental Response Team, Edison, N.J., June.

U.S. Environmental Protection Agency, 1997b. Test Methods for Evaluating Solid Waste, Office of Solid Waste and Emergency Response SW-846, December (incorporating earlier revisions dated 1986, 1992, and 1994).

U.S. Environmental Protection Agency, 1998a. Guidance for Data Quality Assessment, Practical methods for Data Analysis, EPA QA/G-9. January.

U.S. Environmental Protection Agency, 1998b. Guidelines for Ecological Risk Assessment; Notice. Federal Register Vol. 63, No. 93, Thursday May 14, 1998.

U.S. Environmental Protection Agency, 1998c. EPA Guidance for Quality Assurance Project Plans for Environmental Data Operations, EPA QA/R-5. February. 
U.S. Environmental Protection Agency, 1999a. USEPA Contract Laboratory Program Statement of Work for Inorganic Analysis and Classical Chemistry Parameters, Multi-media, Multi-concentration, ILM05.0C. March.

U.S. Environmental Protection Agency, 1999b. USEPA Contract Laboratory Program Statement of Work for Organics Analysis, Multi-media, Multi-concentration, OLM04.2. May.

U.S. Environmental Protection Agency, 1999c. USEPA Contract Laboratory Program, National Functional Guidelines for Organic Data Review - EPA540/R-99/008. October.

U.S. Environmental Protection Agency, 2000. EPA Region 6 Human Health Medium Specific Screening Levels, Background Document, September, Tables, November 15.

WIPP Land Management Plan, DOE/WIPP 93-004

WP 02-EC.05, Quality Assurance Project Plan for WIPP Site Effluent and Hazardous Materials Sampling

WP 02-EC.06, WIPP Site Effluent and Hazardous Materials Sampling Plan

WP 12-FP.01, Fire Protection Program

WP 12-IH.01, WIPP Chemical Hygiene Plan

WP 12-IH.02, WIPP Industrial Hygiene Program

WP 12-IS.01, Industrial Safety Program

WP 13-1, WTS Quality Assurance Program Description

WP 15-PR, WIPP Records Management Program 